\title{
Tracer-based assessment of flow paths, storage and runoff generation in northern catchments: a review
}

\author{
Doerthe Tetzlaff, Jim Buttle, Sean K. Carey, Kevin McGuire, Hjalmar Laudon, \\ Chris Soulsby
}

\begin{abstract}
We examine how tracer studies have enhanced our understanding of flow paths, residence times and sources of stream flow in northern catchments. We define northern catchments as non-glacial sites in the temperate conifer/boreal/permafrost zone, focussing our review mainly on sites in North America and Europe. Improved empirical and theoretical understanding of hydrological functioning has advanced the analytical tools available for tracer-based hydrograph separations, derivation of transit time distributions and tracer-aided rainfall-runoff models that are better able to link hydrological response to storage changes. However, the lack of comprehensive tracer data sets still hinders development of a generalized understanding of how northern catchments will respond to change. This paucity of empirical data leads to many outstanding research needs, particularly in rapidly changing areas that are already responding to climatic warming and economic development. To continually improve our understanding of hydrological processes in these regions our knowledge needs to be advanced using a range of techniques and approaches. Recent technological developments for improved monitoring, distributed hydrological sensor systems, more economic analysis of large sample numbers in conjunction with novel, tracer-aided modelling approaches and the use of remote sensing have the potential to help
\end{abstract}


understanding of northern hydrological systems as well as inform policy at a time of rapid environmental change.

Key words: Tracers, isotopes, runoff processes, North, snowmelt

\section{Introduction}

In this review we examine contributions of tracer studies to understanding northern catchment hydrology. We define "northerness" as post-glacial sites in the boreal/permafrost zone as well as northern temperate mixed/coniferous forests (Figure 1), focussing our review mainly on sites in North America and Europe due to a paucity of published work from Russia. Therefore, the review is limited to northern latitude, upland headwater catchments that are strongly influenced by seasonal snow melt and ground thaw. Importantly, such environments usually have a strong legacy of glaciation, widespread organic soils, and contrasts in unconsolidated glacial materials affecting flow pathways and storage. We believe that our review is timely as climatic warming and development pressures (e.g. mineral extraction) are likely to have profound effects on the hydrology of extensive areas with distinct, seasonal hydroclimatic controls on catchment response (Tetzlaff et al., 2013). Due to the logistical challenges of conventional hydrological monitoring in such environments, tracers are useful tools and have provided integrated insight into the mechanisms of hydrological function. Our first objective is to examine how recent empirical studies have advanced and enriched our understanding of the spatial and temporal variability of dominant flow paths, the residence times of water in different storage zones (snowpack, soil water, glacial till water, etc.) and increasingly an appreciation of the amounts of water held in these different storage zones. Secondly, we highlight some of the main research challenges 
and opportunities related to the application of tracers in the study of northern catchment hydrology. The focus will largely be on small to mesoscale (i.e., 0.1 to $\sim 100 \mathrm{~km}^{2}$ ) well instrumented experimental catchments, but we try to infer the implications for larger scales.

\section{Runoff processes in northern catchments}

Understanding of runoff generation and flow paths is dominated by research conducted in humid temperate regions, where precipitation exceeds evapotranspiration and runoff is largely dominated by subsurface processes (e.g. Dunne et al. 1975; McDonnell 2003). While classical concepts of runoff generation such as saturation overland flow were in part developed in regions with snow (Dunne and Black, 1970), the specific influence of the cryosphere on catchment hydrology is less well represented in the literature. Major uncertainties associated with our understanding of the fate and transport of water even in well-monitored catchments in temperate landscapes (Soulsby et al., 2008) constrain our ability to develop transferable predictive tools to address applied issues such as water resource management, contaminant transport and biogeochemical cycling (Kirchner, 2007). Coupled with this are logistical difficulties associated with access and data collection in such regions (Bishop et al., 2008) and limited application of geophysical techniques in sub-surface characterisation. This is of particular concern given the marked environmental changes that many snow-dominated northern environments are currently experiencing (Adam et al., 2009; MacDonald et al., 2012). There is a limited evidence base from northern headwater catchments in both North America and Eurasia from which to advise policy makers on both the local hydrological impacts of environmental change and how these propagate to larger river systems. 
Relationships between landscape organisation and catchment hydrological response change in different climatic and geomorphic regions as the dominant runoff generation processes vary (Tetzlaff et al., 2009; Carey et al., 2013a). Catchment soils, geology, topology and topography all influence catchment storage, dominant flow paths and short-term responses to water balance dynamics (Buttle, 2006). In many northern landscapes topography is often relatively subdued, reflecting the glacial history and its legacy, and is less strongly invoked as the dominant factor controlling runoff processes. This glacial legacy combined with the cold and often wet hydroclimatic conditions result in landscapes with distinct soils and associated ecohydrological communities (Spence and Woo, 2003; Devito et al., 2005; Verry et al., 2011). Catchment soil cover reflects the integrated interactions of climate, topography, vegetation communities and land use, and soil characteristics play a key role in controlling catchment hydrological responses (Soulsby et al., 2006; Laudon et al., 2007, Bailey et al., 2014). Figure 2 provides a schematic representation of the environmental process controls on runoff generation spanning sites with transient snowpacks (northern Scotland), to more clear seasonal snowpacks in (Sweden) and (northern Canada) where in the latter permafrost is also influential.

Peat soils (or Histosols) often mantle low-lying areas of riparian zones, where runoff generation is dominated by saturation-excess overland flow or rapid flow in transmissive near-surface horizons (Quinton and Marsh, 1999; Soulsby et al., 2004; 2006). The source of water flowing through the active rooting zone in peat soils and riparian zones provides a positive feedback promoting further development of peat landforms (Siegel et al., 2006). These areas can be differentiated from more freely 
draining, podzol soils in upslope areas that serve as recharge zones in catchments (Grabs et al., 2009). Subsurface permeability and hillslope connectedness to riparian areas and the stream network are also important determinants of hydrological response, particularly in areas where extensive glacial drift occurs (Tetzlaff et al., 2014).

The $0^{\circ} \mathrm{C}$ temperature threshold has a remarkable influence on virtually all hydrological processes. The frequency with which the freezing threshold is crossed and the duration that temperatures remain below $0^{\circ} \mathrm{C}$ determine the relative influence of freezing processes on catchment hydrology. More so than more temperate environments, heat and moisture fluxes in northern catchments are closely coupled and are often interdependent (Woo, 1986; Quinton and Carey, 2008). Perhaps the most notable feature influencing the hydrology of northern catchments is the presence of snow, either intermittently or lasting throughout the winter season and releasing water in a single event in the spring freshet (Laudon et al., 2013). The dominance of snow on runoff in much of North America and Eurasia strongly influences runoff pathways and the time for water to travel through the catchment (i.e., transit time) (e.g., Rodhe, 1998). In cold environments, winter redistribution and the lack of mid-winter melt periods can generate deep drifts that have a considerable influence on the runoff response in spring (Woo and Sauriol, 1980; Young and Lewkowicz, 1988; Mielko and Woo, 2006). In addition, the release of a considerable portion of the annual precipitation (up to $\sim 50 \%$ in some regions) during snow melt results in a distinct hydrograph response that is characterized by this annual release. Much of the inter-annual variability in the flow regime of northern catchments is attributable to the influence of snow on the catchment runoff response in any given year, particularly in the warmer parts of the northern region environments (e.g. Spence et al., 2011; Carey et al., 2013a). Although such 
snowmelt influences are particularly marked in upland headwaters, their effects propagate along larger river systems (Woo and Thorne, 2006) to affect the provision of water supplies and other ecosystem services over large spatial scales, throughout much of the year (Barnett et al., 2005).

Like snow, frozen ground is a feature particular to northern regions that strongly influences hydrological response. Frozen soil in winter can cover $55-60 \%$ of the land surface of the Northern Hemisphere (Zhang et al., 1999), and can be categorized as either seasonally or perennially frozen to some depth below the ground surface. In both cases the near-surface zone that is subject to seasonal freeze and thaw has distinct hydrological traits that influence catchment hydrology, largely in terms of storage and its control on the ability of water inputs to infiltrate the soil surface, and partitioning between surface and subsurface flow paths (e.g. Hubbard and Linder, 1986; Hayashi et al., 2003). Unfrozen water content in frozen soils drops markedly as temperatures fall below $0^{\circ} \mathrm{C}$ and ground ice tends to seal openings in soils to render frozen materials largely impervious compared with their unfrozen state, particularly when moisture contents are high. Hydraulic conductivity and liquid storage capacity are therefore temperature dependent and fall sharply as the soil freezes. However, frozen ground does not completely inhibit water movement, and the permeability of frozen soil is largely dependent upon the volume of ice-filled pores (Granger et al., 1984; Laudon et al. 2004; Zhang et al., 2010). Concrete frost (frozen surficial soil whose pores are nearcompletely filled by ice) has a low permeability that restricts infiltration and promotes overland flow (Hardy et al., 2001). This is often observed more frequently in open areas than in forests due, in part, to enhanced night-time radiative cooling in the former (Shanley and Chalmers 1999) and generally greater soil water contents prior to freezing 
(Zhao and Gray 1999). Moreover, changes in snow cover associated with a warming climate could have profound effects on soil frost and therefore hydrological processes (Groffman et al. 2001; Hirota et al. 2006). Similar processes occur in wetlands, another typical feature of northern catchments, where saturated conditions at the onset of winter cause concrete frost, allowing large quantities of water to bypass the soil through overland pathways (Laudon et al., 2007).

Perennially frozen ground occurs sporadically at higher altitudes in parts of the temperate zone, but its importance increases in more northerly locations where its duration is longer and/or permanently frozen ground (termed permafrost) exists. Permafrost is ground that remains at or below $0^{\circ} \mathrm{C}$ for two or more years, and in circumpolar regions is a first-order control on flow paths and runoff (Woo, 1986). It acts as an aquitard, and where continuous, confines flow paths to the near-surface zone, termed the active layer (i.e. the zone of seasonal freeze and thaw). In permafrost environments, soils are subject to physical disturbance by freeze-thaw processes and decomposition of organic matter is often reduced; favouring organic soil development that is widespread in the circumpolar regions. Groundwater from below permafrost seldom reaches the surface (exceptions are some taliks) and there is much less mixing between near-surface and deeper sources than in non-permafrost zones. In discontinuous permafrost environments, the fraction of the catchment underlain with permafrost strongly influences the overall runoff response (Carey and Woo, 1998; Petrone et al., 1997). Permafrost-rich catchments have a flashy runoff response dominated by near-surface drainage, whereas those with seasonal soil frost have much greater baseflow and deeper flow pathways that often connect near-surface and deeper aquifers. Much recent work has highlighted the influence of thawing permafrost on 
altering flow paths, as increasing winter flows and extended recession periods point to the activation of deeper flow pathways (Walvoord et al., 2012).

\section{Use of tracers to understand flow paths and water sources in snow- affected northern catchments}

Environmental tracers, particularly stable isotopes, have been widely used as a means to assess the sources and flow paths of water reaching stream channels in environments ranging from the humid tropics (Buttle and McDonnell, 2005) to the arctic (Cooper et al., 1991). They have become key to investigate hydrological processes and water resources at larger catchment scales beyond the scope of traditional observation approaches (such as measurements of head gradients, hydraulic conductivity fields and porosities), since they naturally integrate field-scale heterogeneity. Thus, in addition to providing information on water provenance, flow paths and transit times, insights from tracer studies supply a valuable means of calibrating or testing more detailed conceptual or numerical models in both smaller experimental (e.g. Seibert et al., 2003; Birkel et al., 2011a) and larger scale catchments (Capell et al., 2012; Stadnyk et al., 2013). The fractionation of water during freeze-melt cycles in snow-influenced systems means that stable water isotopes have been very useful tracers of hydrological processes. The recent development of cheaper, reliable instruments for isotope analysis is showing great potential for ever more widespread and intensive application in northern catchments. 
At the simplest level, quantitative estimates of different water sources and flow paths have been obtained from traditional streamflow hydrograph separations based on the use of geochemical (e.g. silica, electrical conductivity [EC]), dissolved organic carbon (DOC) and isotopic tracers (see Lischeid and Bittersohl (2008) for a comprehensive review). In general, geochemical tracers are used to identify geographical sources (e.g. surface runoff vs. deep groundwater) while isotopic tracers are used to estimate the temporal contribution of different water sources (e.g. event water [water supplied to the catchment by rainfall or snowmelt during a hydrological event] vs. pre-event water [water stored in the catchment prior to the event]). Water isotopes oxygen-18 and deuterium are expressed in standard notation as parts per mille (\%) relative to a standard (V-Standard Mean Ocean Water) as $\delta^{18} \mathrm{O}$ and $\delta^{2} \mathrm{H}$. A traditional approach is the use of two-component hydrograph separations:

$Q_{s}=Q_{1}+Q_{2}$

$Q_{s} C_{s}=Q_{1} C_{1}+Q_{2} C_{2}$

$\frac{Q_{2}}{Q_{s}}=\frac{C_{s}-C_{1}}{C_{2}-C_{1}}$

where $Q_{s}=$ streamflow, $Q_{1}=$ contribution from flow component $1, Q_{2}=$ contribution from flow component $2, C_{s}=$ concentration of tracer in streamflow, $C_{1}=$ concentration of tracer in flow component 1 , and $C_{2}=$ concentration of tracer in flow component 2 .

When isotope tracers are used in an isotopic hydrograph separation (IHS; eq. [3]), the two flow components are generally assumed to represent event and pre-event water. Conversely, when geochemical tracers are used in a geochemical hydrograph separation (GHS), they are often assumed to represent overland flow (which is presumed to undergo little chemical interaction with the surface, and thus, retain the tracer signature of input water) and subsurface flow (which may have a different tracer 
signature compared to input water as a result of biological and chemical interactions with soil, regolith and bedrock).

Following on from pioneering tracer studies in snow-influenced catchments (e.g. Dincer et al., 1990), Rodhe $(1981,1987)$ conducted seminal work in northern catchments using the IHS approach, and demonstrated that pre-event water dominated both the hydrograph peak as well as the total volume of streamflow during spring snowmelt. He also indicated the critical role of surface saturated areas within catchments in delivering meltwater and rainfall to the stream network via saturation overland flow. Rodhe's work inspired the application of IHS to a wide range of northern catchments, largely in Europe (e.g. Bishop et al., 1990) and North America (e.g. Hooper and Shoemaker, 1986; Moore, 1989; Sklash, 1990). This coincided with interest in the influence of different water sources in contributing to episodic surface water acidification in these regions. Most of these studies were conducted in forested catchments, and generally indicated that stormflow during both rainfall and snowmelt is dominated by pre-event water (e.g. Jenkins et al., 1994). In addition, event water contributions were usually highest during spring snowmelt and least during summer rainfall events. The former finding is consistent with the widely-held view that streamflow is largely generated via subsurface water movement. The latter agrees with hydrometric observations that surface saturated areas are at their maximum extent during the snowmelt period as a result of the large input of water to catchments at this time, thus increasing the potential overland transfer of rainwater and snowmelt to the stream (Laudon et al., 2007). When quantifying water release from snowpacks using stable water isotopes, it is critical to account for both the temporal change in the 
snowmelt isotopic signal (e.g., due to fractionation) and the temporary storage of meltwater in the catchment (Laudon et al., 2002).

There has been limited application of isotope studies to more anthropogenically modified environments in northern landscapes. Notable exceptions have been studies such as that of Halldin et al. (1990) in a Swedish city during rainfall, Buttle et al. (1995) in a Canadian suburb during snowmelt, and Soulsby et al. (2014) in a rapidly urbanizing catchment in Scotland. In contrast to findings from forested catchments, they showed that event water dominated peak discharge and total runoff as a result of overland flow generation from impervious surfaces within the catchments. However, there is still limited insight into the cumulative effects such localised impacts of urban development have upon larger river systems.

The use of geochemical tracers to quantify water sources, flow paths (e.g. surface vs. shallow subsurface vs. deep groundwater) and the potential for water movement via preferential pathways through catchment soils in northern environments includes base cations (e.g. Bishop et al., 2000), dissolved silica (e.g. Maulé and Stein, 1990, Buttle and Peters, 1997), alkalinity (e.g. Soulsby et al., 1998, 2007), and DOC (e.g. Peters et al., 1995). Many studies have used both isotopic and geochemical tracers (e.g. Wels et al., 1991; Buttle and Peters, 1997; Laudon and Slaymaker, 1997: Monteith et al., 2006a,b), either employing an expansion of eqs. [1 - 3] in a 3-component hydrograph separation to try and identify both water source and pathway (e.g. Carey and Quinton, 2005), or following the End-Member Mixing Analysis (EMMA) method proposed by Christopherson and Hooper (1992) to separate the catchment hydrograph into flow contributions from multiple sources. Examples of the use of EMMA in 
northern landscapes include Kendall et al. (1999), McEachern et al. (2006), Sebestyen et al. (2008) and Ali et al. (2010).

There are well known assumptions underlying the use of simple and more advanced mixing models (e.g. Buttle, 1994; Klaus and McDonnell, 2013):

1. There is a significant difference between the tracer composition of input water (rainfall, snowmelt) relative to water held in the catchment prior to the event.

2. The tracer composition of input water is constant in space and time, or any variations can be accounted for.

3. The tracer composition of pre-event water is constant in space and time, or any variations can be accounted for. The tracer composition of pre-event water is often taken to be that of baseflow, based on the assumption that it integrates the signature of soil water and groundwater capable of reaching the stream during an event (Rodhe, 1987, Sklash, 1990)

4. Contributions of water from the vadose zone must be negligible, or the tracer content of soil water must be similar to that of groundwater.

5. Contributions to streamflow from surface storage are negligible.

Satisfying all of these assumptions has been particularly problematic in the application of both IHS and GHS in northern environments. Assumption 1 is simply a pre-requisite that is dependent upon event and prevailing environmental conditions. However, there have been a number of studies that have addressed some of the other issues explicitly and advanced the science: 
Addressing assumption 2, the significance of short-term variations in the tracer signal in rainfall inputs in temperate environments for IHS (e.g. McDonnell et al., 1990) and the need to sample this short-term variability using sequential samples also apply when using IHS and GHS in northern landscapes (e.g. Carey and Quinton, 2005). Of special concern for high altitude catchments with seasonal snow cover is the timing and contribution of melt water during spring, when a large portion of the annual runoff is discharged. Applying IHS to snowmelt episodes has its own challenges, since there may be large variations in the event water input signal. Some of this temporal variation is relatively systematic and caused by isotopic fractionation of snowmelt throughout the melt period (Taylor et al., 2002). Superimposed on this gradual enrichment of the isotopic signature of water leaving the snowpack is the melting of layers within the pack with differing isotopic signatures (Taylor et al. 2002) as well as rapid and relatively random changes produced by rain-on-snow (Buttle et al., 1995).

These temporal changes in the event water signature complicate the separation of stream flow into event and pre-event components (Rodhe, 1998). They call into question the validity of using depth integrated snow cores to define the event component (as used e.g. by Rodhe, 1981; Obradovic and Sklash, 1986) since this method does not account for these types of changes in the isotopic signature of water leaving the snowpack. Some studies have attempted to address this by applying an enrichment correction to the isotopic signature obtained from the snow core (Rodhe 1987; Sueker et al. 2000). More recent applications of IHS during snowmelt in northern catchments have used runoff from snowmelt lysimeters (e.g. Moore 1989; Buttle and Sami 1992; Shanley et al. 2002; Carey and Quinton 2004) to represent the tracer signal in input water, thus allowing the temporal variability of $C_{1}$ to be assessed. 
Although the use of snow lysimeters has greatly improved IHS during spring flood episodes, methodological uncertainties associated with the potentially large variation in the isotopic signature of snowmelt water remain. These include the problem of how to account for lateral variation of the event water reservoir across the catchment (e.g. the differential effects of altitude and aspect), and the issue of the integration of temporal variations in the tracer signal of snowmelt inputs over the course of the snowmelt period. In the case of the former, Moore (1989) found no significant difference in the isotopic signature of meltwater from eight snowmelt lysimeters in a small catchment in Quebec. Conversely, Carey and Quinton (2004) found much greater variability and more pronounced fractionation for meltwater from lysimeters on northfacing relative to south-facing slopes in a catchment in the Yukon, Canada. Spatial variability in the meltwater tracer signal can introduce considerable uncertainty into IHS and GHS results, and the most effective way to incorporate such variability into tracer studies in snow-covered catchments is the subject of ongoing research.

Laudon et al. (2002) suggested that the isotopic signature of event water (in this case oxygen-18, $\delta^{18} O_{e}$ ) needs to be adjusted using a runoff corrected event water approach (runCE) ( eq. 4):

$$
\delta^{18} O_{\varepsilon}(t)=\left(\sum_{i=1}^{t} M(i) \delta^{18} O_{m}(i)-\sum_{i=1}^{t} E(i) \delta^{18} O_{\varepsilon}(i)\right) /\left(\sum_{i=1}^{t} M(i)-\sum_{i=1}^{t} E(i)\right)
$$

where $M(i)$ is the incrementally collected melt water depth, and $E(i)$ is the incrementally calculated event water discharge at time $t$ (Eq. 2). $\delta^{18} O_{e}(i)$ and $\delta^{18} O_{m}(i)$ are the event and melt water isotopic compositions, respectively. The runCE method accounts for both the timing and amount of meltwater entering the soil water reservoir, as well as the 
runoff generated by replacing previously melted and subsequently stored water in the soil at every time step during the melt episode. The isotopic composition of this event water is based on a comparison between cumulative snowmelt (and rain water contributions) from snow lysimeters and the cumulative volume (depth) of meltwater that has left the snowpack, but has not yet discharged to the stream during the event. In this way the lag time between the melting of snow and its arrival at the stream is taken into account (Laudon et al., 2002). Although this method has been a step forward it still assumes that the snowmelt behaves as a well-mixed reservoir in the soil. This method has subsequently been used in IHS studies conducted in northern catchments and has resulted in reduced uncertainty in the temporal behaviour of the signature of meltwater inputs (e.g. Carey and Quinton, 2004; Monteith et al., 2006b). Other approaches have been introduced to account for the time variability of event water in IHS (e.g., Weiler et al. 2003); however, they have not been evaluated in snow-dominated catchments.

Addressing assumptions 3 and 4, several studies in northern catchments have documented significant spatial variability in the isotopic signature of baseflow (e.g. Laudon et al., 2007) and near-stream groundwater (e.g. Buttle and Sami, 1992), while others have demonstrated temporal changes in the isotopic signature of soil water and groundwater in response to inputs during an event (e.g. Lindström and Rodhe, 1986, Buttle et al., 1995, McNamara et al., 1997). Whilst such characterization has helped conceptualise heterogeneity, Tetzlaff et al. (2014) showed how the high water content of wetlands in riparian peat soils created a reservoir of storage with a rather constant isotopic composition (Figure 2c). This acted as an "isostat" that mixed and damped inputs from more isotopically heterogeneous hillslope flow paths with displaced water from the valley wetlands in runoff events giving very high ( $90 \%)$ and relatively 
consistent "old" water contributions to streamflow (Tetzlaff et al, 2014). There is potential in combining particle tracking codes with tracer studies to test hypotheses from hydrograph separations regarding how uniform groundwater tracer signals are and how much they contribute to stream flow (Davies et al., 2011). Considerable challenges remain in catchments where permafrost, frozen soil or land use change allow more direct connectivity between slopes and streams and afford less opportunity for mixing (e.g. Figure 2a).

Regarding assumption 5, stores such as lakes and extensive wetlands play an important role in the hydrologic behaviour of many northern catchments. They also complicate the application of IHS in these landscapes (e.g. Metcalfe and Buttle, 2001), particularly if water held in these surface stores has a different tracer signal from those assumed for input water and water held in catchment soils and groundwaters. Buttle and Sami (1992) illustrated how the contributions of this stored water to catchment streamflow can complicate the attribution of streamflow to event and pre-event waters based on IHS results and specific hydrological processes assumed to be operating in the catchment (e.g. groundwater ridging, Sklash and Farvolden, 1979). Thus, the use of tracers to estimate water sources and flow paths must consider the potential changes in tracer composition as water enters, is detained in, and is discharged from lakes and other significant surface stores within a catchment (Gibson and Edwards, 2002). As many larger northern river systems are used for hydropower generation, outflows from reservoirs in both previously natural and man-made water bodies are often regulated. Isotopes have been used to show how such regulation can affect natural variation in stream isotope signals which can help establish hydrological impacts in data sparse areas (e.g. Stadnyk et al., 2013; Soulsby et al., 2015). 


\section{Use of tracers to understand runoff generation dynamics in catchments with seasonally and permanently frozen ground}

There has been limited work on the influence of seasonally frozen ground on the partitioning of event and pre-event water contributions to streamflow. However, a notable study by Shanley et al. (2002) observed greater event water fractions in streamflow from catchments with predominantly open land cover - and hence more prone to frozen ground - compared to more forested catchments in the Sleepers River catchment, northeastern USA. There have also been relatively few applications of tracers to examine water sources and pathways in catchments underlain by permafrost. Nevertheless, the movement of water in permafrost landscapes is of increasing interest in light of atmospheric warming in northern latitudes and the consequent potential alteration of nutrient delivery to receiving waters and surface - atmosphere exchanges of water and carbon (Bowden, 2010).

The presence of permafrost exerts a strong control on the partitioning, storage and release of water, and poses an interesting challenge to the interpretation of tracerbased studies. Permafrost might be expected to preclude significant mixing between event water and pre-event water held in ice-rich soils (Metcalfe and Buttle 2001; Carey and Quinton 2004; Carey et al., 2013b). McNamara et al. (1997) concluded that the spring freshet was supplied largely by meltwater inputs in an Alaskan catchment underlain by continuous permafrost, with pre-event water dominating stormflow hydrographs generated by summer rainfall. Cooper et al. (1991) also found that peak discharge during snowmelt in the same catchment was dominated by meltwater, while Carey and Quinton (2005) noted that streamflow generated by summer rainfall in an alpine basin with discontinuous permafrost was largely pre-event water. The large 
contribution of meltwater to catchment streamflow during snowmelt observed by McNamara et al. (1997) was attributed to limited subsurface storage capacity as a result of a thin or non-existent thawed active layer, and progressive deepening of the active layer increased the contribution of pre-event water to stormflow in the summer. These large event water contributions during snowmelt are inconsistent with estimates of significant pre-event water contributions to streamflow during snowmelt in other permafrost landscapes (e.g. Obradovic and Sklash, 1986; Gibson et al., 1993). This may reflect the previously-mentioned use of integrated snow core samples to estimate event waters contributions in the latter studies, which ignore time-variance during the melt as a result of isotopic enrichment of meltwater leaving the snowpack. For example, Cooper et al. (1993) found that isotopic enrichment in the melting snowpack led to increases in streamflow $\delta^{18} \mathrm{O}$ which might be interpreted as an increased pre-event water contribution. Conversely, Boucher and Carey (2010) and Carey et al. (2013b) used snowmelt lysimeters and observed event water fractions in spring freshet runoff in a discontinuous permafrost alpine catchment in Yukon, Canada ranging from 0.1 to 0.26 during four years of monitoring, suggesting that contributions of displaced deeper subsurface water dominated catchment streamflow.

The study by Carey and Quinton (2004) in the same catchment provides valuable insight into water source and flow path dynamics during the critical snowmelt period. Permafrost distribution defined runoff contributing areas, while active layer development on permafrost slopes resulted in a gradual decrease in meltwater contribution to streamflow during snowmelt such that streamflow was dominated by pre-event water by the end of melt. Chemical tracers (DOC, EC) indicated that the dominant flow path at the start of melt was via the organic horizon on permafrost- 
underlain slopes, transitioning to the mineral substrate as the active layer developed. Most water delivered from the slopes to the stream during the spring freshet was premelt water, which was attributed to the ability of meltwater to infiltrate frozen ground, mix with and displace pre-event waters. Both McNamara et al. (1997) and Carey and Quinton (2004) suggested that the pre-event water component in streamflow from permafrost catchments at the start of snowmelt is water held in the ubiquitous organic soil that mantles the slopes. Inter-catchment differences in the relative contributions of event and pre-event water to streamflow from permafrost catchments documented in the limited number of studies to date may reflect differences in the extent of permafrost (discontinuous vs. continuous) and the size and geometry of the network of potential runoff contributing areas.

Although less accessible in the English-based literature, isotope studies in Russia are significantly enriching our understanding of hydrological processes and runoff generation in permafrost regions. This includes process-based work that shows the relative importance of seasonal snowmelt, summer rain, and melt released from permafrost on maintaining summer soil moisture over different years at the Spasskaya Pad experimental forest near Yakutsk (Sugimoto et al., 2003). These components affect soil moisture availability and variability in water balance partitioning; factors that are likely to be extremely sensitive to climate change (Sugimoto et al., 2002). In addition, the use of isotopes in plant cellulose in lake sediments has been used by Wolfe and Edwards (1997) to develop techniques to infer palaeo-hydrological regimes in lakes, in terms of the strength of annual melt influence in the western Taymir peninsula. 
Figure 3 conceptualises the potential changes in fractions of total streamflow during spring melt with changing annual average air temperature for catchments ranging in land cover from forest to urban areas. At the coldest (permafrost) end of the temperature spectrum, all catchments display a similar response: large event water contributions to streamflow due to movement of rain- and meltwater via surface and near-surface pathways on frozen soils. The event water fraction of spring streamflow decreases with increasing air temperatures. There is a shift to seasonally frozen soils in all catchments due to a reduction in overland flow and greater contributions from subsurface pre-event water. However, catchments dominated by wetland soils have consistently larger event water fractions relative to forested catchments due to greater soil water contents prior to freeze-up and consequently greater saturated and frozen soil coverage during spring melt. With further increases in temperature there is a similar dominance of streamflow by pre-event water regardless of the prevailing land cover for forest, agricultural and wetland catchments. For urban catchments in northern environments, high event water contributions dominate independent of mean annual temperatures.

\section{Estimating water transit and residence times in northern systems}

Over the past decade, tracer studies have greatly enhanced our understanding of the temporal dynamics of different flow paths and water stores in northern catchments. The elapsed time between water entry to and exit from a catchment as stream discharge at the outlet is the transit or travel time of water (Figure 4). The residence time of water is the elapsed time from water entry into the catchment for water within the storage of the catchment. Estimation of transit time using lumped parameter inverse modelling of isotopic tracers has a long history in northern and snow-dominated catchments (e.g. 
Dinçer et al., 1970; Maloszewski et al., 1983; Rodhe et al., 1996; Lyon et al., 2010). Snow-dominated catchments usually have isotopic signals that are considerably depleted in isotopic composition compared to rainfall or water stored in the catchment prior to the onset of snowmelt (Rodhe, 1998). This isotopic deviation makes snowmeltdominated catchments useful places for exploring water transit time.

While transit time estimation techniques were largely developed for quasisteady-state groundwater systems, there has been considerable interest in adapting the approaches for catchment systems (McGuire and McDonnell, 2006; Hrachowitz et al., 2009; McDonnell et al., 2010), including new theoretical and observation studies on time-variant or non-stationary systems (Davies et al., 2011; Botter et al., 2011; Heidbüchel et al., 2012; Hrachowitz et al., 2013; Birkel et al., 2014). Here, we focus on northern and snow-dominated catchments and what has been learned from transit time studies in these systems. Transit times provide information on flow paths, storage, release, and chemical quality of water and integrate various catchment functions and processes (Figure 4). For example, transit times and their variation with time (e.g., Hrachowitz et al., 2010) allow the quantification of catchment storage, which may help resolve such poorly understood processes in catchments and their role in runoff activation, modulation of effects of environmental change, contaminant fate and transport (Kirchner et al., 2000), and the degree to which flow paths are connected to the stream (Tetzlaff et al., 2014).

Transit times allow the identification of catchments dominated by rapid, surface flow paths or by deeper subsurface flows, thus providing useful information in comparing catchment function (e.g., Tetzlaff et al., 2009). Figure 5 contrasts the transit 
time distribution (TTD) for two small catchments in Scotland, where (a) at Loch Ard in the Central Highlands is dominated by hydrologically fast responding soils (such as Histosols and shallow Regosols) and (b) at Sourhope in the Cheviot Hills is dominated by freely draining soils (Podzols) and large groundwater aquifers. In the first, the predominance of near-surface flow paths results in rapid routing and mean transit times of a few months compared to the latter which is characterised by slower routing and mean transit times of several years (Hrachowitz et al, 2009b).

Permafrost, frozen ground, and the accumulation and release of snow water equivalent all will influence transit times; yet there have been only limited studies to date looking at transit times in cold catchments. Precipitation and contaminants originating from atmospheric deposition accumulate over the winter season in such catchments and are released over short periods of time during snowmelt. This accumulation or delay and episodic release of water and solutes make it an important process to understand for runoff generation and the fate of chemical constituents stored within the snowpack of northern catchments (Cooper et al., 1991). Seminal work by Lindström and Rodhe (1992) used lysimeters to trace the isotope variation in snowmelt through the profile of till soil, with the melt pulse having a transit time of between 2-5 months to reach $80 \mathrm{~cm}$ depth. Similar time scales were observed for the response of the soils of the Gardsjön catchment from both empirical (Rodhe et al., 1996) and modelling studies (Davies et al., 2011). Similarly, Lyon et al. (2010) found that the mean transit times associated with snowmelt water release varied from about 20 to 180 days at 16 sites in northern Sweden and depended on landscape factors such as percentage of wetland areas and average site gradient. As discussed previously, shallow ice layers or discontinuous permafrost develop impervious boundaries to vertical infiltration during 
snowmelt periods, and thus alter the flow paths of water in the landscape and influence transit time (Walvoord et al., 2012). Lyon et al. (2010) suggested that potential thaw of these ice layers due to climate change could increase mean transit times at the catchment scale by 20 to $45 \%$ assuming different soil and till thicknesses.

Several recent reviews and commentaries have addressed issues associated with transit time estimation in catchments (Maloszewski and Zuber, 1993; McGuire and McDonnell, 2006; Hrachowitz et al., 2010; McDonnell et al., 2010; Kirchner et al., 2010; Beven, 2010; Botter et al. 2010). Estimates of mean transit times, although useful, are limited in how much they can tell us about the behaviour of a system, because the mean value is highly dependent on the nature of the full transit time distribution and, in particular, the tails (short and long transit times) of the distribution, which are difficult to quantify. However, when longer tracer time series with high frequency samples are available for estimating transit times, uncertainty is likely to be reduced because the record length is more similar to the timescale associated with the tails on the TTDs (Kirchner et al., 2000). Furthermore, the shape of the TTD is often indicative of the aggregation of physical heterogeneities affecting flow processes, which may allow for the theoretical derivation of TTD form (e.g., Kirchner et al., 2001; Lindgren et al., 2004).

Uncertainty in estimates of transit times can be reduced when estimates from multiple tracers converge on similar values. Different tracers can constrain transit times for different portions for the transit time spectrum (e.g., Stewart et al., 2010). Stable isotopes typically provide transit time information for values less than about 4-5 years; in contrast, tritium or other tracers such as chlorofluorocarbons (CFCs) can provide 
information over much longer time spans. There are several examples of transit time estimates in snow-dominated catchments where tritium has been used to estimate transit time (e.g., Dinçer et al., 1970; Maloszewski et al., 1983). Such mixed methodologies have considerable potential in northern systems where relatively young waters $(<$ a few years) involved in the spring melt may circulate over groundwater which may be decades old or permafrost which may be even older. There are technical challenges, however, in developing tritium deposition records for northern sites, while CFC methods can be problematic in snowy regions and are sensitive to accurate estimates of recharge temperatures.

The attempts to estimate water transit times though various stores (e.g. soil water, groundwater) also have methodological challenges. Many of the same models estimating water transit times (e.g. exponential, dispersion) are used to relate temporal variations in the tracer signal of soil or groundwater to the signature of input water at the soil surface. Water transit times represent the average length of time needed for water to move from the ground surface to the point of sampling, with longer times implying greater opportunity for water to interact with soil and regolith, and thus greater geochemical transformation. Previous work suggests that the spatial distribution of transit times may be correlated with variations in topographic properties within a catchment such as the Beven and Kirkby (1979) topographic index, assuming that water residence time at a given point increases with greater recharge area and reduced local gradient (Rodhe et al., 1996). However, this hypothesis is not supported by results from the limited work conducted during snowmelt in northern landscapes (Buttle et al. 2001; Monteith et al., 2006b), partly as a result of the considerable uncertainty associated with 
transit time estimates due to changes in tracer signals over a relatively short time period such as spring snowmelt.

\section{Potential future research directions}

The challenges posed by northern catchments have resulted in more general advances in tracer hydrology. New technical, empirical and theoretical advances in hydrology will further enhance our understanding of flow paths, storage and runoff responses in northern in the coming decade. Some of the more promising ones are summarised in Table 1 and discussed below.

Our ability to incorporate temporal (and to a lesser extent spatial) variations in the tracer composition of rainwater and snowmelt inputs into hydrograph separations outlined earlier has improved our capability to identify water sources and flow paths in these regions. Recent advances have enabled this knowledge to be used in the development of tracer-aided models to improve understanding of system function from headwater to the larger watershed scales (Davies et al., 2011; Hrachowitz et al., 2013; Stadynk et al., 2013). Further improvements in the reliability of automatic water samplers and the availability of laser spectroscopy, which can facilitate high resolution isotopic sampling at relatively low cost (e.g. Lyon et al., 2009; Birkel et al., 2010a), also have significant implications for future applications of tracers in northern hydrological

research. These developments enable daily or sub-daily sampling of precipitation and streamflow over long periods, thus providing tracer data at timescales more comparable with hydrometric data than was previously the case (Birkel et al., 2010b). The resulting data sets will be crucial to studying the controls on inter-catchment differences in water transit and residence times in northern landscapes. Such data can enhance the potential 
use of hydrological models as learning frameworks in hypothesis testing of northern system functions, especially as near real time monitoring of soil and ground water isotope composition is becoming achievable.

Advances in hydrograph separation methods will also benefit from richer data sets as the community has moved beyond the use of two-component mixing models to examine water sources and flow paths (Burns, 2002). The greater use of multiple tracer studies employing multivariate statistical methods which extend traditional EMMA approaches will refine further our ability to differentiate water sources and flow paths. These studies form an integral component of combined approaches using distributed hydrometric networks, Geographical Information Systems and remote sensing in the analysis of water sources, flow paths, transit and residence times in northern landscapes.

A recent focus with major advances in tracer hydrology has been the use of tracers to estimate catchment-scale storage (Soulsby et al, 2009; McNamara et al., 2011). Storage changes can modulate tracer signals and act as controls on a wide range of hydrological, chemical and biological functions of a catchment (Tetzlaff et al., 2011). The nature of the relationship between catchment subsurface water storage and discharge has been well recognized as the fundamental underpinning of many rainfallrunoff models (e.g. Kirchner, 2009). However, freezing of soil water in northern systems strongly influences this relationship, and adequate representation of temperature-moderated storage is critical, particularly for predicting hydrological responses to a changing climate. Environmental tracers play a critical role in understanding these relations between storage and discharge in different landscape units (Birkel et al., 2011b; Soulsby et al., 2011) and there is now potential for integrating 
such work with spatially distributed physical measurements of storage change (through geophysics, COSMOS probes and microgravity).

Several studies in low-gradient, northern wetland landscapes have integrated stable isotope, chemical and hydrometric data to investigate the importance of storage dynamics for runoff generation (e.g. Hayashi et al., 2003). Spence et al. (2011) defined the hydrological function of wetlands as oscillating between two states: one where water was simply transmitted through the wetland and another where the wetland contributed runoff from storage. Functional thresholds could be identified to show when different landscape units were connected to generate stream flow. Recent work in the Scottish Highlands indicated that small changes in dynamic storage in riparian wetlands governed runoff generation during small inputs to the catchment (Tetzlaff e al., 2014). In contrast, larger events mobilized water in the steeper catchment hillslopes leading to the expansion of saturated areas and a non-linear increase in runoff response as the catchment exhibited greater connectivity. As noted earlier, the extensive riparian wetlands in many northern landscapes act as "isostats" with large residual catchment storage volumes where mixing of different catchment source waters occurs. Whilst the dynamic storage changes, which moved the catchment between its wettest and driest phases, were $<100 \mathrm{~mm}$; the total storage inferred to explain tracer damping was $>1000 \mathrm{~mm}$. Similar patterns of storage-mediated linkages between riparian zones and uplands were also observed in the snow-dominated environment of the northwestern USA where Jencso et al. (2010) quantified the temporal links between hillslopes and near-stream zones. 
As noted earlier, many northern landscapes are currently responding to shifts in precipitation and air temperature associated with climate change. Several authors have provided integrated conceptual models of how this non-stationarity will affect the ecohydrological function of catchments (Hinzman et al., 2013; Tetzlaff et al., 2013). These include the role of increasing air temperatures in extending the period of ground thaw and deepening the active layer at the end of the thaw period, with consequences for the partitioning of precipitation inputs between surface and subsurface pathways. Discontinuous permafrost cover will disappear from many regions while in others continuous permafrost will become discontinuous in spatial extent. Conceptual models such as Figure 2 may serve as the basis for developing research hypotheses regarding event vs. pre-event water partitioning in catchment streamflow as air temperatures increase. There is an urgent need to examine the role that the thermal and water holding properties of various land covers in northern landscapes may play in modulating the effects of a warmer climate on water storage, transfer and export, and tracers are useful tools for such investigations.

Coupled with increases in air temperature are shifts in the partitioning of precipitation inputs between rain and snow. Reductions in the temporal duration of snowcover as well as the amount of water retained in the snowpack throughout the winter will influence the depth and spatial extent of frozen soil, and thus soil hydrological processes. Mid-winter streamflow may increase in response to greater frequency of rain-on-snow events (Surfleet and Tullos, 2013), with important implications for nutrient export from northern catchments (Casson et al., 2010). Advances in the date of spring snowmelt have already been documented in many northern landscapes (Whitfield 2013), and these changes (coupled with potential 
reductions in peak streamflow during the spring freshet as a result of a reduction in the snow water equivalent prior to melt) may lead to changes in the hydrologic regime of northern catchments. Tracer applications and tracer aided models have potential in providing integrated assessments for how these changes are likely to affect runoff generation processes and the downstream delivery of water supplies and other ecosystem services on which growing populations in northern regions depend.

\section{Conclusion}

Tracer studies have played an important role in understanding and modelling the hydrology of snow-influenced catchments over the past 30 years. Further progress over the coming decades seems assured. Application of new technology, ever closer combination of empirical and modelling studies in research design and integration of new data streams with theoretical developments makes this an exciting time for northern region hydrology. As the effects of climate change become more apparent and our understanding of how non-stationarities and threshold behaviour affect catchment function improved, the scientific evidence-base to inform management at this critical time will continue to grow. 


\section{Acknowledgements:}

We thank the European Research Council ERC (project GA 335910 VEWA) for funding the VeWa project.

\section{References}

Adam JC, Hamlet A, Lettenmaier DP. 2009. Implications of global climate change for snowmelt hydrology in the twenty-first century. Hydrological Processes 23: 962-972.

Ali GA, Roy AG, Turmel M-C, Courchesne F. 2010. Source-to-stream connectivity assessment through end-member mixing analysis. Journal of Hydrology dOI:10.1016/j.jhydrol.2010.07.049

Anderson SP, Dietrich WE, Montgomery DR, Torres R, Conrad ME, Loague K. 1997. Subsurface flow paths in a steep, unchanneled catchment. Water Resources Research 33: 2637-2653.

Bailey SW, Brousseau PA, McGuire KJ, Ross DS. 2014. Influence of landscape position and transient water table on soil development and carbon distribution in a steep, headwater catchment. Geoderma, doi:10.1016/j.geoderma.2014.02.017.

Barnett TP, Adam JC, Lettenmaier DP. 2005. Potential impacts of a warming climate on water availability in snow-dominated regions. Nature 438(7066): 303-309.

Beven KJ, Kirkby MJ. 1979. A physically based, variable contributing area model of basin hydrology. Hydrological Sciences Bulletin 24: 43-69.

Beven KJ. 2010. Preferential flows and travel time distributions: defining adequate hypothesis tests for hydrological process models. Hydrological Processes 24: 1537-1547.

Birkel C, Dunn SM, Tetzlaff D, Soulsby C. 2010a. Assessing the value of high-resolution isotope tracer data in the stepwise development of a lumped conceptual rainfall-runoff model. Hydrological Processes 24: 2335-2348.

Birkel C, Tetzlaff D, Dunn SM, Soulsby C. 2010b. Towards a simple dynamic process conceptualization in rainfall-runoff models using multi-criteria calibration and tracers in temperate, upland catchments. Hydrological Processes 24: 260-275.

Birkel C, Tetzlaff D, Dunn SM, Soulsby C. (2011a) Using time domain and geographic source tracers to conceptualise streamflow generation processes in lumped rainfall-runoff models. Water Resources Research 47, W02515, doi: 10.1029/2010WR009547.

Birkel C, Soulsby C, Tetzlaff D. (2011b) Modelling catchment-scale water storage dynamics: reconciling dynamic storage with tracer-inferred passive storage. Hydrological Processes 25: 3924-3936.

Birkel, C., Soulsby, C. and Tetzlaff, D. (2014) Developing a consistent process-based conceptualization of catchment functioning using measurements of internal state variables. Water Resources Research. DOI:10.1002/2013WR014925.

Bishop KH, Grip H, O'Neill A. 1990. The origins of acid runoff in a hillslope during storm events. Journal of Hydrology 116: 35-61.

Bishop KH, Laudon H, Köhler S. 2000. Separating the natural and anthropogenic components of spring flood $\mathrm{pH}$ decline: a method for areas that are not chronically acidified. Water Resources Research 36: 1873-1884.

Bishop KH, I. Buffam, M. Erlandsson, J. Fölster, H. Laudon, J. Seibert and J. Temnerud. 2008. Aqua Incognita: the unknown headwaters. Hydrological Processes 22: 1239-1242.

Botter G, Bertuzzo E, Rinaldo A. 2011. Catchment residence and travel time distributions: The master equation. Geophysical Research Letters 38, DOI: 10.1029/2011GL047666 
Boucher JL, Carey SK. 2010. Exploring runoff processes using chemical, isotopic and hydrometric data in a discontinuous permafrost catchment. Hydrology Research 41: 506519.

Bowden WB. 2010. Climate change in the Arctic - Permafrost, thermokarst, and why they matter to the non-Arctic world. Geography Compass 4: 1553-1566.

Burns DA. 2002. Stormflow-hydrograph separation based on isotopes: the thrill is gone - what's next? Hydrological Processes 16: 1515-1517.

Buttle JM. 1994. Isotope hydrograph separations and rapid delivery of pre-event water from drainage basins. Progress in Physical Geography 18: 16-41.

Buttle J. 2006. Mapping first-order controls on streamflow from drainage basins: the T3 template. Hydrological Processes 20, 3415-3422.

Buttle JM, Sami K. 1992. Testing the groundwater ridging hypothesis of streamflow generation during snowmelt in a forested catchment. Journal of Hydrology 135: 53-72.

Buttle JM, Peters DL. 1997. Inferring hydrological processes in a temperate basin using isotopic and geochemical hydrograph separation: a re-evaluation. Hydrological Processes 11: 557-573.

Buttle JM, Vonk AM, Taylor $\mathrm{CH}$. 1995. Applicability of isotopic hydrograph separation in a suburban basin during snowmelt. Hydrological Processes 9: 197-211.

Buttle JM, Hazlett PW, Murray CD, Creed IF, Jeffries DS, Semkin R. 2001. Prediction of groundwater characteristics in forested and harvested basins during spring snowmelt using a topographic index. Hydrological Processes 15: 3389-3407

Buttle JM, McDonnell JJ. 2005. Isotope tracers in catchment hydrology in the humid tropics, In: Bonell M, Bruijnzeel LA (eds), Forest-Water-People in the Humid Tropics: Past, Present and Future Hydrological Research for Integrated Land and Water Management, Cambridge University Press, 770-789.

Capell R, Tetzlaff D, Soulsby C. 2012. Can time domain and source area tracers reduce uncertainty in rainfall-runoff models in larger heterogeneous catchments? Water Resources Research. 48, W09544. doi:10.1029/2011WR011543

Carey SK, Woo MK. 1998. Snowmelt hydrology of two subarctic slopes, southern Yukon, Canada. Nordic Hydrology, 29: 331-346.

Carey SK, Tetzlaff D, Buttle J, Laudon H, McDonnell J, McGuire K, Seibert J, Soulsby C, Shanley J. (2013a) Use of colormaps and wavelet coherence to discern short and longerterm climate influences on streamflow variability in northern catchments. Water Resources Research. doi: 10.1002/wrcr.20469.

Carey SK, Boucher JL, Duarte CM. 2013b. Inferring groundwater contributions and pathways to streamflow during snowmelt over multiple years in a discontinuous permafrost environment (Yukon Canada). Hydrogeology Journal 21: 67-77.

Carey SK, Quinton WL. 2004. Evaluating snowmelt runoff generation in a discontinuous permafrost catchment using stable isotope, hydrochemical and hydrometric data. Nordic Hydrology 35: 309-324.

Carey SK, Quinton WL. 2005. Evaluating runoff generation during summer using hydrometric, stable isotope and hydrochemical methods in a discontinuous permafrost alpine catchment. Hydrological Processes 19: 95-114.

Casson N, Eimers MC, Buttle JM. 2010. The contribution of rain-on-snow events to nitrate export in the forested landscape of south-central Canada, Hydrological Processes 24: 1985-1993.

Christopherson N, Hooper RP. 1992. Multivariate analysis of stream water chemical data: the use of principal components analysis for the end-member mixing problem. Water Resources Research 28: 99-107.

Cooper LW, Olsen CR, Solomon DK, Larsen IL, Cook RB, Grebmeier JM. 1991. Stable isotopes of oxygen and natural and fallout radionuclides used for tracing runoff during snowmelt in an Arctic watershed. Water Resources Research 27: 2171-2179. 
Cooper LW, Solis C, Kane DL, Hinzman LD. 1993. Application of oxygen-18 tracer techniques to Arctic hydrological processes. Arctic Alpine Res. 25: 247-255.

Davies J, Beven K, Nyberg L, Rodhe A. 2011. A discrete particle representation of hillslope hydrology: hypothesis testing reproducing a tracer experiment at Gardsjon, Sweden, Hydrological. Processes 25: 3602-3612.

Devito K, Creek I, Gan T, Mendoza C, Petrone R, Silins U, Smerdon B. 2005. A framework for broad-scale classification of hydrologic response units on the Boreal Plain: is topography the last thing to consider? Hydrological Processes 19: 1705-1714.

Dinçer T, Payne BR, Florkowski T, Martinec J, Tongiorgi E. 1970. Snowmelt runoff from measurements of tritium and oxygen-18. Water Resources Research 6: 110-124.

Dunne T, Black RD. 1970. Partial area contributions to storm runoff in a small New England watershed, Water Resources Research 6: 1296-1311.

Dunne, T., Moore, T., \& Taylor, C. H. (1975). Recognition and prediction of runoff-producing zones in humid regions. Hydrological. Sciences Bulletin 20: 305-327.

Gibson JJ, Edwards TWD, 2002. Regional surface water balance and evaporation-transpiration partitioning from a stable isotope survey of lakes in northern Canada. Global Biogeochemical Cycles, 16: 10.1029/2001GB001839, 2002.

Gibson JJ, Edwards TWD, Prowse TD. 1993. Runoff generation in a high boreal wetland in northern Canada. Nordic Hydrology 24: 213-224.

Grabs T, Seibert J, Bishop K, Laudon H. 2009. Modeling spatial patterns of saturated areas: A comparison of the topographic wetness index and a dynamic distributed model, Journal of Hydrology, 373, 15-23.

Granger RJ, Gray DM, Dyck GE. 1984. Snowmelt infiltration to frozen Prairie soils. Canadian Journal of Earth Sciences 21: 669-677.

Groffman PM, Driscoll CT, Fahey TJ, Hardy JP, Fitzhugh RD, Tierney GL. 2001. Colder soils in a warmer world: a snow manipulation study in a northern hardwood forest ecosystem. Biogeochemistry 56: 135-150.

Halldin S, Rodhe A, Bjurman B. 1990. Urban storm water transport and wash-off of caesium137 after the Chernobyl accident. Water, Air and Soil Pollution 49: 139-158.

Hardy JP, Groffman PM, Fitzhugh RD, Henry KS, Welman AT, Demers JD, Fahey TJ, Driscoll CT, Tierney GL, Nolan S. 2001. Snow depth manipulation and its influence on soil frost and water dynamics in a northern hardwood forest. Biogeochemistry 56: 151-174.

Hayashi M, van der Kamp G, Schmidt R. 2003. Focused infiltration of snowmelt water in partially frozen soil under small depressions. Journal of Hydrology 270: 214-229.

Heidbüchel I, Troch PA, Lyon SW, Weiler M. 2012. The master transit time distribution of variable flow systems. Water Resources Research 48. DOI: 10.1029/2011WR011293

Hinzman LD, Deal, CJ, McGuire D, Mernild SH, Polyakov IV, Walsh JE (2013) Trajectory of the Arctic as an integrated system. Ecological Applications 23: 1837-1868.

Hirota T, Iwata Y, Hayashi, M, Suzuki S, Hamasaki T, Sameshima R, Takayabu I. 2006. Decreasing soil-frost depth and its relation to climate change in Tokachi, Hokkaido, Japan. Journal of the Meteorological Society of Japan 84: 821-833.

Hooper RP, Shoemaker CA. 1986. A comparison of chemical and isotopic hydrograph separation. Water Resources Research 22: 1444-1454.

Hrachowitz M, Soulsby C, Tetzlaff D, Dawson JJC, Dunn SM, Malcolm IA. 2009. Using longterm data sets to understand transit times in contrasting headwater catchments. Journal of Hydrology 367: 237-248.

Hrachowitz M, Soulsby C, Tetzlaff D, Malcolm IA, Schoups G. 2010. Gamma distribution models for transit time estimation in catchments: Physical interpretation of parameters and 
implications for time-variant transit time assessment. Water Resources Research 46, DOI: 10.1029/2010WR009148

Hrachowitz M, Savenije H, Bogaard TA, Tetzlaff D, Soulsby C. 2013. What can flux tracking teach us about water age distribution patterns and their temporal dynamics? Hydrology and Earth Systems Science 17: 533-564.

Hubbard DE, Linder RL. 1986. Spring runoff retention in prairie pothole wetlands. Journal of Soil and Water Conservation 41: 122-125.

Jencso KG, McGlynn BL, Gooseff MN, Bencala KE, Wondzell SM. 2010. Hillslope hydrologic connectivity controls riparian groundwater turnover: Implications of catchment structure for riparian buffering and stream water sources, Water Resources Research 46, W10524, doi:10.1029/2009WR008818.

Jenkins A, Ferrier RC, Ogunkoya RO. 1994. A case study in hydrochemistry: conflicting interpretations from hydrological and chemical observations. Hydrological Processes 8: 335349.

Jones JP, Sudicky EA, Brookfield AE, Park Y-J., 2006. An assessment of the tracer-based approach to quantify groundwater contributions to streamflow. Water Resources Research 42, W02407, doi:10.1029/2005WR004130

Kendall KA, Shanley JB, McDonnell JJ. 1999. A hydrometric and geochemical approach to test the transmissivity feedback hypothesis during snowmelt. Journal of Hydrology 219: $188-$ 205.

Kirchner JW, Feng X, Neal C. 2000. Fractal stream chemistry and its implications for contaminant transport in catchments. Nature $403: 524-527$. DOI: 10.1038/35000537

Kirchner JW, Feng X, Neal C. 2001. Catchment-scale advection and dispersion as a mechanism for fractal scaling in stream tracer concentrations. Journal of Hydrology 254 : 82-101.

Kirchner JW. 2007. Getting the right answers for the right reasons: linking measurements, analyses, and models to advance the science of hydrology. Water Resources Research 42 , W03S04.

Kirchner JW. 2009. Catchments as Simple Dynamical Systems: Catchment Characterization, Rainfall-Runoff Modeling, and Doing Hydrology Backward, Water Resources Research 45, W02429, doi:10.1029/2008WR006912.

Kirchner JW, Tetzlaff D, Soulsby C. 2010. Comparing chloride and water isotopes as hydrological tracers in two Scottish catchments. Hydrological Processes 24 : 1631-1645.

Klaus, J., \& McDonnell, J. J. (2013). Hydrograph separation using stable isotopes: Review and evaluation. Journal of Hydrology 505: 47-64.

Laudon H, Slaymaker O. 1997. Hydrograph separation using stable isotopes, silica and electrical conductivity: an alpine example. Journal of Hydrology 201: 82-101.

Laudon H, Köhler S, Seibert J, Bishop H. 2004. Hydrological flow paths during the spring flood: Congruence between hydrometric measurements and oxygen-18 in snow melt, soil water, and runoff, Water Resources Research 40: W03102 10.1029/2003WR002455.

Laudon, Sjöblom V, Buffam I, Seibert J, Mörth CM. 2007. The role of catchment scale and landscape characteristics for runoff generation of boreal streams. Journal of Hydrology 344: 198-209.

Laudon H, Tetzlaff D, Soulsby C, Carey S, Seibert J, Buttle J, Shanley J, McDonnell J, McGuire K. 2013. Change in winter climate will affect dissolved organic carbon and water fluxes in mid-to-high latitude catchments. Hydrological Processes 27: 700-709.

Laudon H, Hemond HF, Krouse R, Bishop KH. 2002. Oxygen 18 fractionation during snowmelt: Implications for spring flood hydrograph separation. Water Resources Research 38: 40-1$40-10$. 
Lindgren GA, Destouni G, Miller AV. 2004. Solute transport through the integrated groundwaterstream system of a catchment. Water Resources Research 40, DOI: 10.1029/2003WR002765

Lindström G, Rodhe A. 1986. Modelling water exchange and transit times in till basins using oxygen-18. Nord. Hydrol. 17: 325-334.

Lindström G, Rodhe A, 1992. Transit times of water in soil lysimeters from modelling of oxygen18. Water, Air and Soil Polllution 65: 83-100.

Lischeid G, Bittersohl J. 2008. Tracing biogeochemical processes in stream water and groundwater using non-linear statistics. Journal of Hydrology 357, no. 1-2 (July 30): 11-28.

Lyon SW, Desilet SLW, Troch PA. 2009. A tale of two isotopes: differences in hydrograph separation for a runoff event when using $\delta D$ versus $\delta^{18} O$. Hydrological Processes 23: 20952101.

Lyon SW, Laudon H, Seibert J, Mörth M, Tetzlaff D, Bishop KH. 2010. Controls on snowmelt water mean transit times in northern boreal catchments. Hydrological Processes 24: 16721684.

MacDonald RJ, Byrne JM, Boon S, Kienzle SW. 2012. Modelling the potential impacts of climate change on snowpack in the North Saskatchewan River Watershed, Alberta. Water Resources Management 26: 3053-3076.

Maloszewski P, Rauert W, Stichler W, Herrmann A. 1983. Application of flow models in an alpine catchment area using tritium and deuterium data. Journal of Hydrology 66: 319-330.

Maloszewski P, Zuber A. 1993. Principles and practice of calibration and validation of mathematical models for the interpretation of environmental tracer data in aquifers. Advances in Water Resources 16: 173-190.

Maulé CP, Stein J. 1990. Hydrologic flow path definition and partitioning of spring meltwater. Water Resources Research 26: 2959-2970

McDonnell JJ, Bonell M, Stewart MK, Pearce AJ. 1990. Deuterium variations in storm rainfall: implications for stream separation. Water Resources Research 26: 455-458.

McDonnell JJ. 2003. Where does water go when it rains? Moving beyond the variable source area concept of rainfall-runoff response. Hydrological Processes 17: 1869-1875.

McDonnell JJ, McGuire K, Aggarwal P, Beven K, Biondi D, Destouni G, Dunn S, James A, Kirchner J, Kraft P, Lyon S, Malowszewski P, Newman L, Pfister L, Rinaldo A, Rodhe A, Sayama T, Seibert J, Soloman K, Soulsby C, Stewart M, Tetzlaff D, Tobin C, Troch P, Weiler M, Western A, Wormann A, Wrede S. 2010. How old is streamwater? Open questions in catchment transit time conceptualization, modelling and analysis. Hydrological Processes 24: 1745-1754.

McEachern P, Prepas EE, Chanasyk DS. 2006. Landscape control of water chemistry in northern boreal streams of Alberta. Journal of Hydrology 323: 303-324.

McGuire KJ, McDonnell JJ. 2006. A review and evaluation of catchment transit time modeling. Journal of Hydrology 330 : 543-563.

McNamara JP, Kane DL, Hinzman LD. 1997. Hydrograph separations in an Arctic watershed using mixing model and graphical techniques. Water Resources Research 33: 1707-1719.

McNamara JP, Tetzlaff D, Bishop K, Soulsby C, Seyfried M, Peters N, Hooper R. 2011. Storage as a metric of catchment comparison. Hydrological Processes 25: 3364-3371.

Metcalfe RA, Buttle JM. 2001. Soil partitioning and surface store controls on spring runoff from a boreal forest peatland basin in north-central Manitoba, Canada. Hydrological Processes 15: 2305-2324.

Mielko C, Woo M-k. 2006. Snowmelt runoff processes in a headwater lake and its catchment, subarctic Canadian Shield. Hydrological Processes 20: 987-1000. 
Monteith SS, Buttle JM, Hazlett PW, Beall FD, Semkin RG, Jeffries DS. 2006a. Paired-basin comparison of hydrological response in harvested and undisturbed hardwood forests during snowmelt in central Ontario: I. Streamflow, groundwater andflow path behaviour. Hydrological Processes 20: 1095-1116.

Monteith SS, Buttle JM, Hazlett PW, Beall FD, Semkin RG, Jeffries DS. 2006b. Paired-basin comparison of hydrological response in harvested and undisturbed hardwood forests during snowmelt in central Ontario: II. Streamflow sources and groundwater residence times. Hydrological Processes 20: 1117-1136.

Moore RD. 1989. Tracing runoff sources with deuterium and oxygen-18 during spring melt in a headwater catchment, southern Laurentians, Quebec. Journal of Hydrology 112: 135-148.

Obradovic MM, Sklash MG. 1986. An isotopic and geochemical student of snowmelt runoff in a small arctic watershed. Hydrological Processes 1: 15-30.

Pearce, A. J., Stewart, M. K., \& Sklash, M. G. (1986). Storm runoff generation in humid headwater catchments: 1 . Where does the water come from? Water Resources Research 22: $1263-1272$

Peters DL, Buttle JM, Taylor CH, LaZerte BD. 1995. Runoff production in a forested, shallow soil, Canadian Shield basin. Water Resources Research 31: 1291-1304.

Petrone K, Buffam I, Laudon H (2007) Hydrologic and biotic control of nitrogen export during snowmelt: A combined conservative and reactive tracer approach, Water Resources Research, 43(6), doi:10.1029/2006WR005286.

Quinton WL, Marsh P. 1999. A Conceptual Framework for Runo€ Generation in a Permafrost Environment. Hydrological Processes 13: 2563-2581.

Quinton WL, Carey SK. 2008. Towards an energy based runoff generation theory for tundra landscapes. Hydrological Processes 22: 4949-4653.

Rodhe A. 1981. Spring flood: Meltwater or groundwater? Nordic Hydrology 12: 21-30.

Rodhe A. 1987. The origin of streamwater traced by oxygen-18. PhD Thesis, Department of Physical Geography, Division of Hydrology, Rep. Ser. A 40, Uppsala University, 152 pp.

Rodhe A. 1998. Snowmelt-dominated systems. In Isotope Tracers in Catchment Hydrology, Kendall C and McDonnell JJ (eds). Elsevier; 391-434.

Rodhe A, Nyberg L, Bishop K. 1996. Transit times for water in a small till catchment from a step shift in oxygen-18 content of the water input. Water Resources Research 32: 3497-3511.

Sebestyen SD, Boyer EW, JShanley JB, Kendall C, Doctor DH, Aiken GR, Ohte N. 2008. Sources, transformations, and hydrological processes that control stream nitrate and dissolved organic matter concentrations during snowmelt in an upland forest, Water Resources Research 44:W12410, doi:10.1029/2008WR006983.

Seibert, J., A.Rodhe, K.Bishop, 2003. Simulating interactions between saturated and unsaturated storage in a conceptual runoff model, Hydrological Processes, 17: 379-390

Siegel DI, Glaser PH, So J, Janecky DR. 2006. The dynamic balance between organic acids and circumneutral groundwater in a large boreal peat basin. Journal of Hydrology 320: 421431.

Shanley JB, Chalmers A. 1999. The effect of frozen soil on snowmelt runoff at Sleepers River, Vermont. Hydrological Processes 13: 1843-1857.

Shanley JB, Kendall C, Smith TE, Wolock DM, McDonnell JJ. 2002. Controls on old and new water contributions to stream flow at some nested catchments in Vermont, U.S.A. Hydrological Processes 16: 589-609.

Sklash MG. 1990. Environmental isotope studies of storm and snowmelt runoff generation. In: Anderson MG, Burt TP (eds), Process Studies in Hillslope Hydrology, Wiley: Chichester, 401-435. 
Sklash MG, Farvolden RN. 1979. The role of groundwater in storm runoff. Journal of Hydrology 43: 45-65.

Soulsby C, Chen M, Ferrier RC, Jenkins A, Harriman R. 1998. Hydrogeochemistry of shallow groundwater in a Scottish catchment. Hydrological Processes 12: 1111-1127.

Soulsby C, Rogers P, Petry J, Hannah D, Dunn SM, Malcolm IA. 2004. Using tracers to upscale flow path understanding in mesoscale mountainous catchments: two examples from Scotland. Journal of Hydrology 291: 172-294.

Soulsby C, Tetzlaff D, Rodgers P, Dunn S., Waldron S. 2006. Runoff processes, stream water residence times and controlling landscape characteristics in a mesoscale catchment: An initial evaluation. Journal of Hydrology 325: 197-221.

Soulsby C, Tetzlaff D, van den Bedem N, Malcolm IA, Bason PJ, and Youngson AF. 2007. Inferring groundwater influences on surface water in montane catchments from hydrochemical surveys of springs and streamwaters. Journal of Hydrology 333: 199-213.

Soulsby C, Neal C, Laudon H, Burns DA, Merot P, Bonell M, Dunn SM, Tetzlaff D. 2008. Catchment data for process conceptualization: simply not enough? Hydrological Processes 22, 2057-2061.

Soulsby C, Tetzlaff D, Hrachowitz M. 2009. Tracers and transit times: windows for viewing catchment scale storage? Hydrological Processes 23 : 3503-3507. DOI: 10.1002/hyp.7501

Soulsby C, Piegat K, Seibert J, Tezlaff D. 2011. Catchment scale estimates of flow path partitioning and water storage based on transit time and runoff modelling. Hydrological Processes. DOI: 10.1002/hyp.8324.

Soulsby C, Birkel C, Tetzlaff D. (2014) Assessing urbanization impacts on catchment transit times. Geophysical Research Letters 41, doi:10.1002/2013GL058716.

Soulsby C, Birkel C, Geris J, Tetzlaff D. (2015) The isotope hydrology of a large river system regulated for hydropower. Rivers Research Applications. DOI: 10.1002/rra.2740.

Spence, C., and M. K. Woo (2003), Hydrology of subarctic Canadian shield: soil-filled valleys, Journal of Hydrology 279: 151-166.

Spence C, Guan X, Phillips R. (2011) The hydrological functions of a boreal wetland. Wetlands 31: 75-85, doi:10.1007/s13157-010-0123-X.

Stadnyk TA, Kouwen N, Edwards TWD. 2013. Mesoscale model validation and calibration using Stable Water Isotopes: the isoWATFLOOD Model. Hydrological Processes. DOI: 10.1002/hyp.9695

Stewart MK, Morgenstern U, McDonnell JJ. 2010. Truncation of stream residence time: how the use of stable isotopes has skewed our concept of streamwater age and origin. Hydrological Processes 2 : 1646-1659. DOI: 10.1002/hyp.7576

Sueker JK, Ryan JN, Kendall C, Jarrett RD. 2000. Determination of hydrologic pathways during snowmelt for alpine/subalpine basins, Rocky Mountain National Park, Colorado. Water Resources Research 36: 63-75.

Sugimoto A, Anagisawa N, Naito D, Fujita N, Maximov TC. (2002) Importance of permafrost as a source of water for plants in east Siberian taiga. Ecological Research 17, 493-503.

Sugimoto A, Naito D, Yanagisawa N, Ichiyanagi K, Kurita N, Kubota J, Kotake T, Ohata T, Maximov TC, Fedorov AN. (2003) Characteristics of soil moisture in permafrost observed in East Siberian taiga with stable isotopes of water. Hydrological Processes 17, 1073-1092.

Surfleet CG, Tullos D. 2013. Variability in effect of climate change on rain-on-snow peak flow events in a temperate climate. Journal of Hydrology 479: 24-34.

Taylor S, Feng X, Williams M, McNamara J. 2002. How isotopic fractionation of snowmelt affects hydrograph separation. Hydrological Processes 16: 3683-3690. 
Tetzlaff D, Seibert J, Soulsby C. 2009. Inter-catchment comparison to assess the influence of topography and soils on catchment transit times in a geomorphic province; the Cairngorm mountains, Scotland. Hydrological Processes 23: 1874-1886. DOI: 10.1002/hyp.7318

Tetzlaff D, McNamara JP, Carey SK. (2011) Measurements and modelling of storage dynamics across scales. Hydrological Processes 25: 3831-3835.

Tetzlaff D, Soulsby C, Buttle J, Capell R, Carey SK, Kruitbos L, Laudon H, McDonnell J, McGuire K, Seibert S, Shanley J. 2013. Catchments on the Cusp? Structural and functional change in northern ecohydrological systems. Hydrological Processes 27: 766-774.

Tetzlaff D, Birkel C, Dick J, Soulsby C. 2014. Storage dynamics in hydropedological units control hillslope connectivity, runoff generation and the evolution of catchment transit time distributions. Water Resources Research. DOI: 10.1002/2013WR014147.

Verry ES, Brooks KN, Nichols DS, Ferris DR,, Sebesteyen SD. 2011, Watershed Hydrology, in Kolka R. K., Sebesteyen S. D., Verry E.S., Brooks K. N. (Eds), CRC Press, 193-213.

Walvoord MA, Voss Cl, Wellman TP. 2012. Influence of permafrost distribution on groundwater flow in the context of climate-driven permafrost thaw: Example from Yukon Flats Basin, Alaska, United States. Water Resources Research 48, DOI: 10.1029/2011WR011595

Weiler M, McGlynn BL, McGuire KJ, McDonnell JJ. 2003. How does rainfall become runoff? A combined tracer and runoff transfer function approach. Water Resources Research 39(11). DOI: 10.1029/2003WR002331

Wels C, Cornett RJ, LaZerte BD. 1991. Hydrograph separation: a comparison of geochemical and isotopic tracers. Journal of Hydrology 122: 253-274.

Whitfield PH. 2013. Is 'Centre of Volume' a robust indicator of changes in snowmelt timing? Hydrological Processes 27: 2691-2698.

Wolfe BB, Edwards TWD. 1997. Hydrologic control on the oxygen-isotope relation between sediment cellulose and lake water, western Taimyr Peninsula, Russia: implications for the use of surface-sediment calibrations in paleolimnology. Journal of Paleolimnology 18: 283291.

Woo M-K. 1986. Permafrost hydrology in North America. Atmosphere - Ocean 24: 201-234.

Woo M-K, Sauriol J. 1980. Channel development in snow-filled valleys, Resolute, N.W.T., Canada. Geografiska Annaler 62A: 37-56.

Woo M-k, Thorne R. 2006. Snowmelt contribution to discharge from a large mountainous catchment in subarctic Canada. Hydrological Processes 20: 2129-2139.

Young KL, Lewkowicz AG. 1988. Measurement of outflow from a snowbank with basal ice. Journal of Glaciology 34: 358-362.

Zhang T, Barry RG, Knowles K, Heginbottom JA, Brown J. 1999. Statistics and characteristics of permafrost and ground-ice distribution in the Northern Hemisphere. Polar Geography 23: 132-154. doi: 10.1080/10889379909377670.

Zhang Y, Carey SK, Quinton WL, Janowicz JR, Pomeroy JW, Flerchinger GN. 2010. Comparison of algorithms and parameterisations for infiltration into organic-covered permafrost soils. Hydrology and Earth Systems Science 14: 729-750

Zhao L, Gray DM. 1999. Estimating snowmelt infiltration into frozen soils. Hydrological Processes 13: 1827-1842. 
Table 1: Scientific advances likely to lead to development of tracer hydrology in northern regions; developments are mapped on to the three main themes of this review

\begin{tabular}{|c|c|c|c|}
\hline & Flow paths & Storage & Runoff generation \\
\hline $\begin{array}{l}\text { High frequency } \\
\text { temporal } \\
\text { sampling of } \\
\text { tracers }\end{array}$ & $\begin{array}{l}\text { Near continuous monitoring of tracers is now } \\
\text { theoretically possible with field deployable } \\
\text { instruments. Whilst currently mainly focused on } \\
\text { precipitation and stream flow for time variant } \\
\text { transit time assessment, applications to other } \\
\text { fluxes (preferential soil water flows, } \\
\text { groundwater, transpiration etc) have potential. }\end{array}$ & $\begin{array}{l}\text { High frequency sampling of slowly } \\
\text { changing stores will provide } \\
\text { information on short-term mixing } \\
\text { processes. }\end{array}$ & $\begin{array}{l}\text { Near-real time monitoring of tracer variations in } \\
\text { rainfall and runoff will enhance understanding } \\
\text { of event-based source contributions and their } \\
\text { associated transit times distributions. Higher } \\
\text { resolution insights into both snowmelt and } \\
\text { rainfall events. }\end{array}$ \\
\hline $\begin{array}{l}\text { Hydropedology } \\
\text { and improved } \\
\text { characterisation } \\
\text { of soil-water } \\
\text { interactions }\end{array}$ & $\begin{array}{l}\text { Recent work has highlighted the critical role of } \\
\text { soils, but work in the north is limited. e.g. } \\
\text { improved extraction methods and the "two } \\
\text { water worlds" hypothesis suggests strong } \\
\text { partitioning and poor mixing of matrix and } \\
\text { preferential flows in non-northern environments. } \\
\text { Also, the relative role of summer rain, snow melt } \\
\text { and permafrost thaw in maintaining soil moisture } \\
\text { is poorly understood. }\end{array}$ & $\begin{array}{l}\text { The partitioning of soil water } \\
\text { storage between different pore } \\
\text { sizes and different phases (liquid } \\
\text { and ice) becoming clearer. Also, } \\
\text { use of spatially integrating methods } \\
\text { (e.g. COSMOS probes, } \\
\text { microgravity) allow assessment of } \\
\text { storage changes. }\end{array}$ & $\begin{array}{l}\text { The emergence of hydrological connectivity as } \\
\text { a concept and identification of threshold } \\
\text { behaviour are allowing extrapolation of the role } \\
\text { of soil moisture status in the spatial and } \\
\text { temporal dynamics of runoff response. Also } \\
\text { implications for improved understanding of } \\
\text { threshold-response in snowmelt. Both help in } \\
\text { assessing how time variant transit times evolve } \\
\text { at the catchment scale. }\end{array}$ \\
\hline $\begin{array}{l}\text { Vegetation- } \\
\text { hydrology } \\
\text { feedbacks }\end{array}$ & $\begin{array}{l}\text { Increased attention on the catchment-scale role } \\
\text { of vegetation, LiDAR identification of canopy } \\
\text { structure influence on precipitation partitioning. } \\
\text { Use of CT-scan of soil cores to assess root } \\
\text { influence on macropores. }\end{array}$ & $\begin{array}{l}\text { Importance of canopy for } \\
\text { redistribution of precipitation (e.g. } \\
\text { snow accumulation \& melt, } \\
\text { throughfall/stem flow influence on } \\
\text { recharge) is recognised as is } \\
\text { spatial variation of interception and } \\
\text { ET rates on subsurface storage }\end{array}$ & $\begin{array}{l}\text { Catchment scale effects of vegetation are } \\
\text { increasingly more fully appreciated and being } \\
\text { conceptualised in models. Spatial and } \\
\text { temporal scaling of vegetation influence on } \\
\text { stream flow generation is an obvious area of } \\
\text { improved conceptualisation in runoff models. }\end{array}$ \\
\hline Geophysics & $\begin{array}{l}\text { Near surface geophysics (ERT and GPR) and } \\
\text { tracer tests can identify preferential flows and } \\
\text { spatially extrapolate to larger areas. }\end{array}$ & $\begin{array}{l}\text { Characterising storage architecture } \\
\text { in soils, glacial drifts and weathered } \\
\text { bedrock. Potential for } \\
\text { characterising permafrost extent. }\end{array}$ & $\begin{array}{l}\text { Less impact, but understanding of } \\
\text { relationships between storage and runoff will } \\
\text { be improved. }\end{array}$ \\
\hline $\begin{array}{l}\text { Non-stationary } \\
\text { analysis }\end{array}$ & $\begin{array}{l}\text { Increased availability of long terms data sets are } \\
\text { showing effects of non-stationarity and extreme } \\
\text { events in water balance components, resulting } \\
\text { variation in dominant flows paths and impacts on } \\
\text { transit time distributions. }\end{array}$ & $\begin{array}{l}\text { Improved understanding of the } \\
\text { interaction of hydroclimate, } \\
\text { vegetation and landscape controls } \\
\text { on storage and memory effects }\end{array}$ & $\begin{array}{l}\text { Characterisation of how catchments are never } \\
\text { the same and transit through different state } \\
\text { with dynamics of actively contributing and } \\
\text { connected areas. Guidance for ungauged } \\
\text { basins and limitations of traditional methods }\end{array}$ \\
\hline $\begin{array}{l}\text { Modelling as } \\
\text { learning } \\
\text { frameworks }\end{array}$ & $\begin{array}{l}\text { Models increasingly used to test hypotheses } \\
\text { about dominant flow paths at a range of scales. } \\
\text { A challenge in northern environments is process } \\
\text { complexity and resulting equifinality }\end{array}$ & $\begin{array}{l}\text { Tracer-aided models will help } \\
\text { constrain estimates of the relative } \\
\text { importance of passive and dynamic } \\
\text { storage in different catchments. }\end{array}$ & $\begin{array}{l}\text { Both low parameter and highly distributed } \\
\text { models have potential in northern catchments } \\
\text { for testing hypotheses of runoff response at a } \\
\text { range of spatial and temporal scales. }\end{array}$ \\
\hline
\end{tabular}


Figures:

Figure 1: Distribution of sites where studies in this review are located.

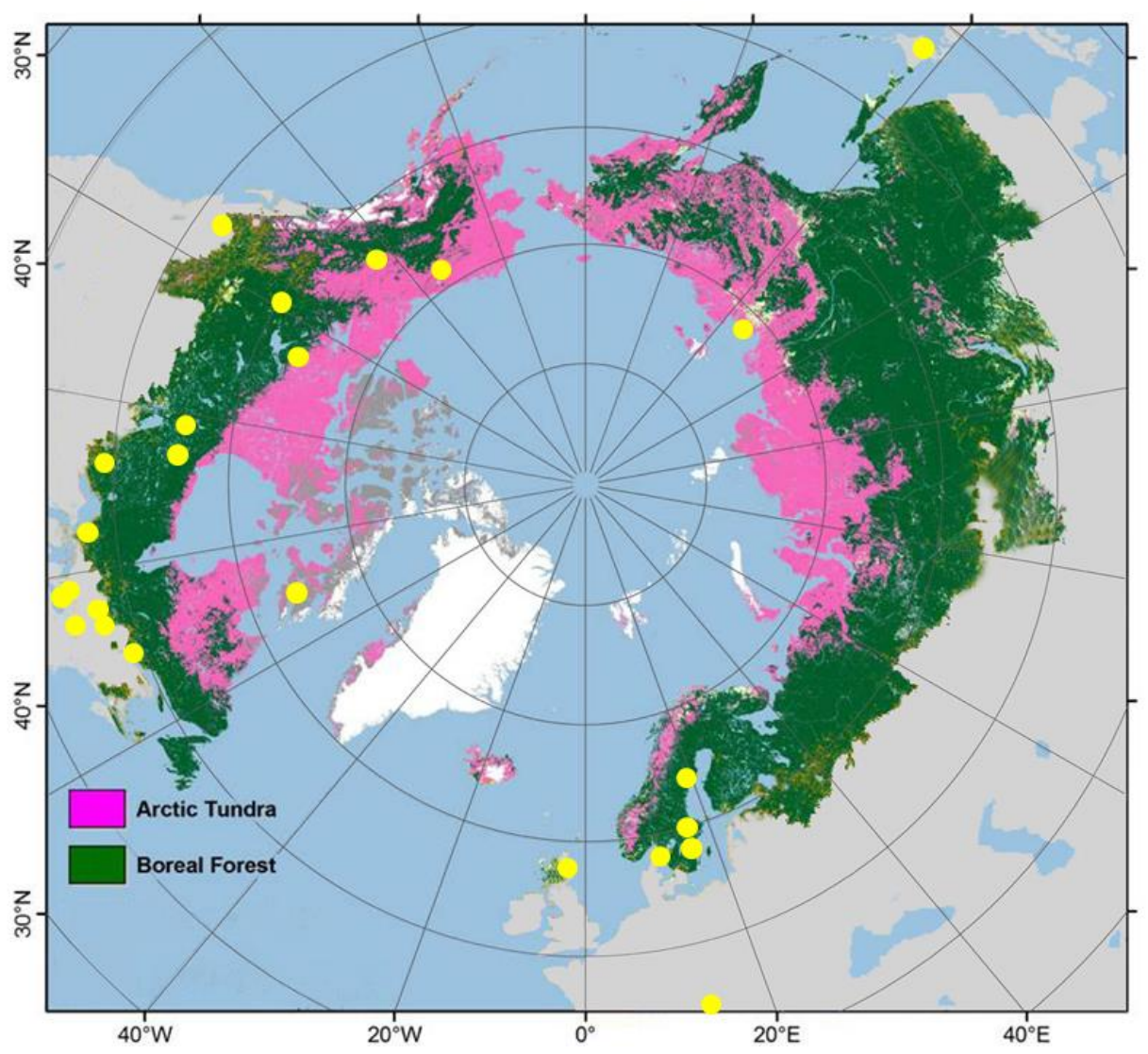


Figure 2: Characteristic runoff generation processes in Northern landscapes showing conceptual graphics of a transect of sites from permafrost zones (Wolf Creek, Canada, (a)), through boreal forests zone (Krycklan, Sweden (b)) to the southern end of the boreal zone at Girnock, Scotland (c).

\section{a)}

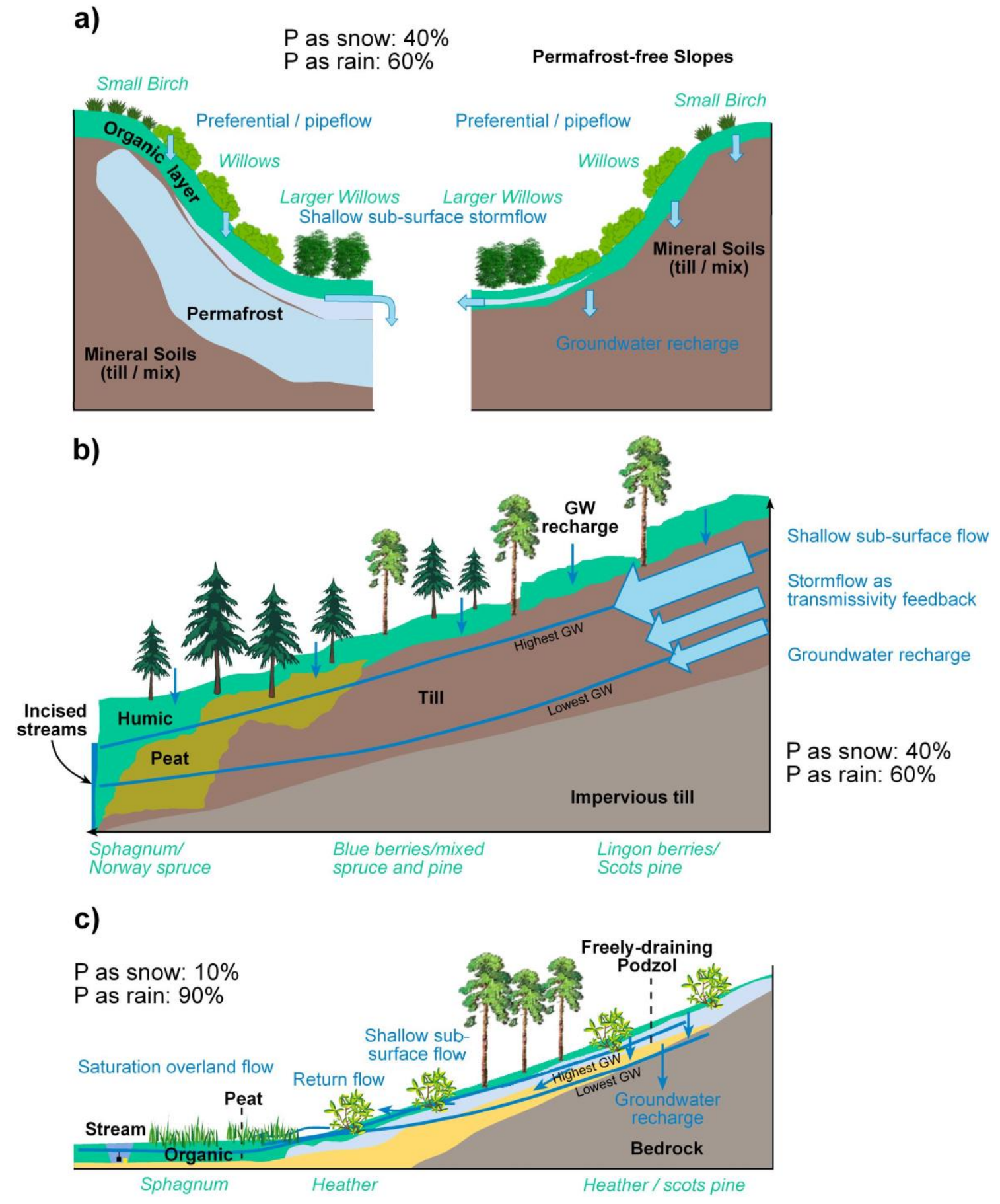


Figure 3: Conceptual model of the hypothesized change in event water contribution to Spring runoff in catchments dominated by different land cover and in response to changes in annual average air temperature.

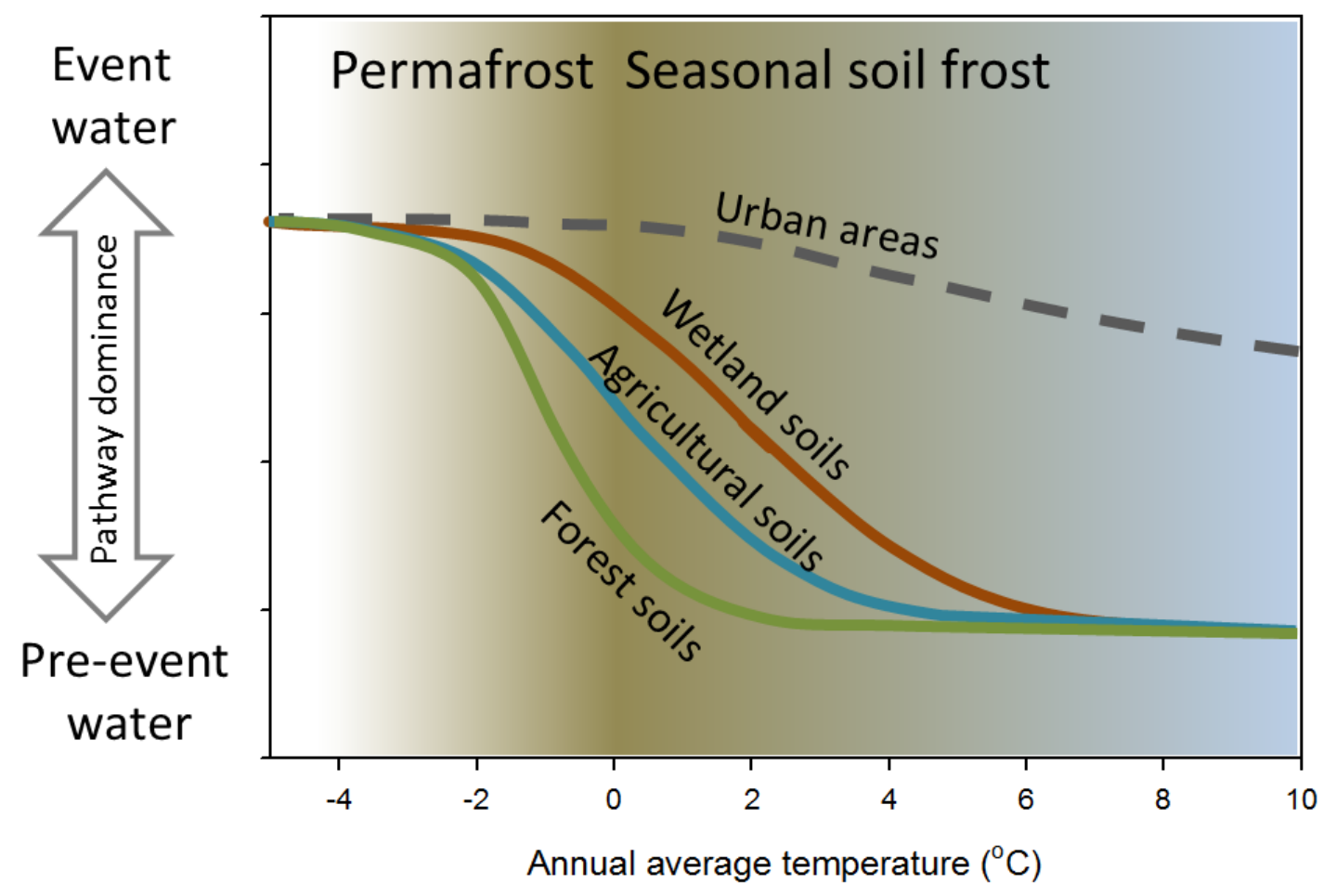


Figure 4: Conceptualisation of how spatially distributed inputs received by a catchment travel along heterogeneous flow paths to the catchment outlet (output). The diagram shows how a conservative tracer input to a catchment will be 'filtered' as the water passes through the system to the catchment outlet, yielding a damped and lagged signal with less high-frequency variation (after McGuire and McDonnell, 2006).

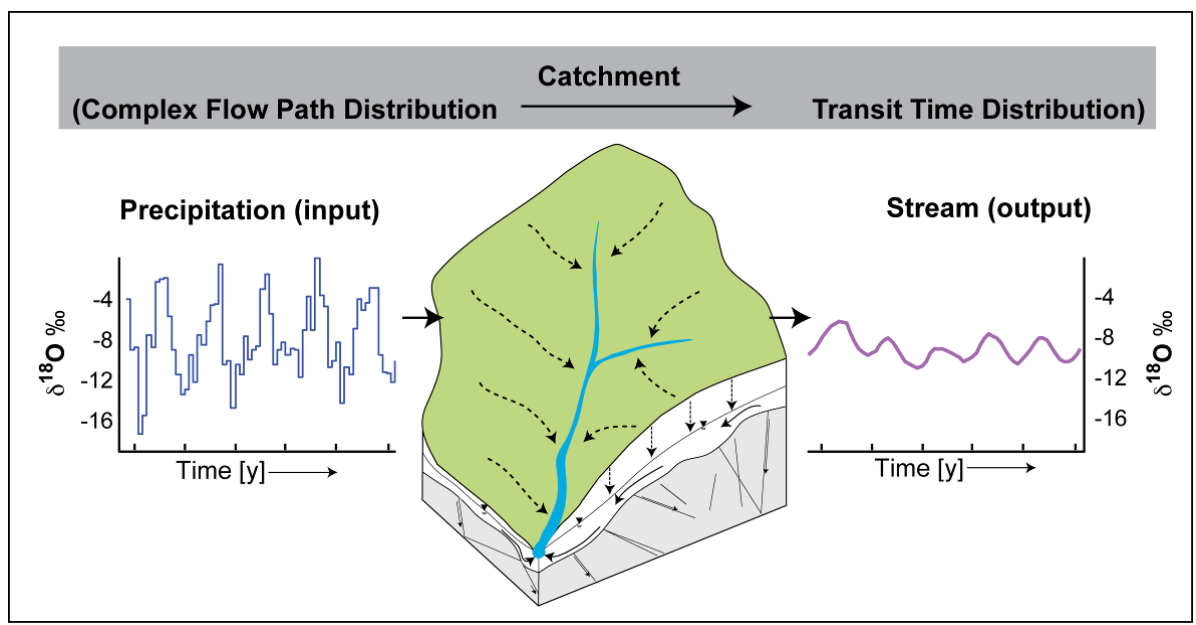


Figure 5: Examples of cumulative transit times distributions for a hydrologically fast responding catchment (Loch Ard, Central Scottish Highlands (a)) and a catchment with a damped response (Sourhope in the Cheviot Hills, Scotland (b)). Transit time models are EM: Exponential Model; EPM: Exponential Piston Flow Model; TPLR: Two Parallel Linear Reservoir Model, Dispersion Model, Gamma Model. (after Hrachowitz et al., 2009).
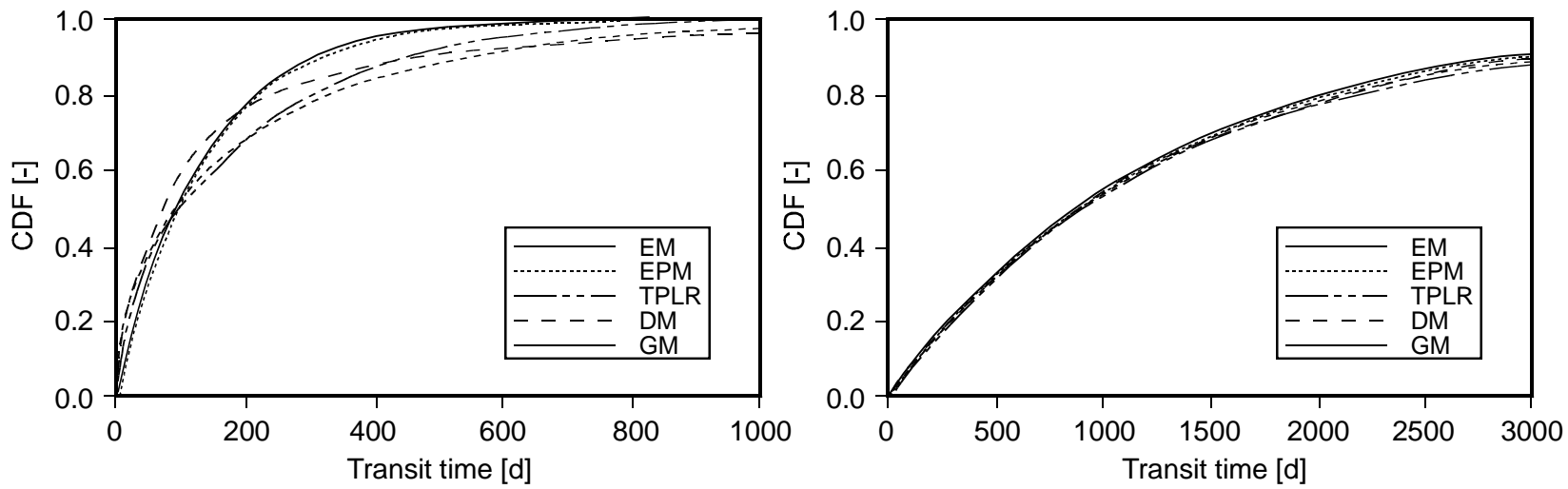